\title{
CONE-760658--1
}

\section{RECOVERY OF CRYSTALLINITY IN GROUND CALCITE}

R. B. Gammage

Oak Ridge National Laboratory

$$
\text { and }
$$

D. R. Glasson

Plymouth Polytechnic

By acceptance of this article, the publisher or recipient acknowledges the U.S. Government's right to retain a non-exclusive, royalty-free license in and to any copyright covering the article.

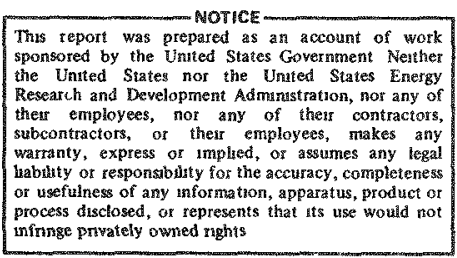




\section{DISCLAIMER}

This report was prepared as an account of work sponsored by an agency of the United States Government. Neither the United States Government nor any agency Thereof, nor any of their employees, makes any warranty, express or implied, or assumes any legal liability or responsibility for the accuracy, completeness, or usefulness of any information, apparatus, product, or process disclosed, or represents that its use would not infringe privately owned rights. Reference herein to any specific commercial product, process, or service by trade name, trademark, manufacturer, or otherwise does not necessarily constitute or imply its endorsement, recommendation, or favoring by the United States Government or any agency thereof. The views and opinions of authors expressed herein do not necessarily state or reflect those of the United States Government or any agency thereof. 


\section{DISCLAIMER}

Portions of this document may be illegible in electronic image products. Images are produced from the best available original document. 


\title{
RECOVERY OF CRYSTALLINITY IN GROUND CALCITE*
}

\author{
R. B. Gammage \\ Oak Ridge National Laboratory \\ D. R. Glasson \\ Plymouth Polytechnic
}

\begin{abstract}
Recovery processes by thermal treatment and recrystallization are examined in a calcite specimen severely disordered by ball milling. As the annealing temperature is increased, restructuring in the bulk lags behind the recovery of crystalline perfection in the surface regions. Surface reordering is significant at temperatures as $20 w$ as $250-175^{\circ} \mathrm{C}$ and is rapidly completed at $400^{\circ} \mathrm{C}$. Annealing at $600^{\circ} \mathrm{C}$ is required for removal of all lattice strain. Before loss of surface can occur by sintering, the temperature needs to exceed $300^{\circ} \mathrm{C}$. The corresponding temperature for a high-area precipitated calcite is $400^{\circ} \mathrm{C}$. Recovery of crystallinity is also promoted by light-etching with aqueous acid when extensive whisker growth occurs. Aging over a period of twelve years has led to loss of the ultrareactive characteristics.
\end{abstract}

\section{INTRODUCTION}

Previous researches $(1-7)$ have shown that the ball milling of calcium carbonate has a pronounced effect on the surface and structural properties of the crystals. In detailed studies of the effect of grinding on large crystals of Iceland spar, the crystal structure became disordered with the appearance of noncrystalline and strained conditions. The grinding operation proceeded in three distinct and clearly defined stages with respect to the degree of crystalline perfection of the calcite, viz, (1) crystal fracture by cleavage, with the degree of crystallinity remaining unchanged; (2) plastic deformation of the crystals (shown by electron microscopy), with some production

Research sponsored by the Energy Research and Development Administration under contract with Union Carbide Corporation and the Science Research Council, United Kingdom. 
of noncrystalline material (contributing to the absorption of $X$-rays, but not to the reflected intensity), and (3) progressive distortion of the crystal lattice (indicated by $X$-ray line-broadening and infrared absorption measurements). The transformation of calcite into aragonite, by ball milling under "thin film" conditions, can be regarded as a further stage in the disturbance of the crystal structure. The X-ray measurements indicated that the crystals of calcite had to be worked until the amount of lattice distortion reached a critical level before any phase transformation occurred.

Development of defective crystal structure in the Iceland spar enabled water molecules to penetrate increasingly into the interior of the grains. The crystals, in which the lattice was believed to be distorted, recrystallized slowly in the presence of water, and whiskers of nail-head spar calcite were formed. Within the deformed crystals, the structure was most disordered in the superficial regions which modified the surface properties. The structural degradation of the superficial regions increased the apparent solubility of the calcite, so that it increased stepwise, most considerably at the start of the second and third milling stages.

These results strongly supported the suggestion that dislocations were the defects primarily responsible for the structural degradation of the calcite crystals and that the particles of the samples milled for longer times, e.g., $1000 \mathrm{~h}$, were strain-hardened. The development and storing of lattice imperfections - especially dislocations - within the strained crystals increase the free energy compared with that of the unstrained material. The process by which strain-hardening diminishes is called recovery and is enhanced by rise in temperature.

In the present research, further information on the nature and location of the defects has been obtained by studying the recovery of crystallinity of the milled material by heat treatment and light-etching with aqueous acid.

\section{MATERTALS AND EXPERIMENTS}

The precipitated calcite was obtained, as a reagent grade material, from the John and E. Sturge Co., Birmingham, England. The optical grade crystals of natural Iceland spar were ground for $1000 \mathrm{~h}$ in a stainless steel ball mill, with the pot filled to $40 \%$ of its volume by a $1-\mathrm{kg}$ charge. $X$-ray fluorescence analysis of the milled sample showed it to contain only $60 \mathrm{ppm}$ 
of iron; thus, little wearing of the steel surfaces had occurred. $X$-ray diffraction showed that there had been no phase transition of calcite into aragonite. The large amount of calcite (1-kg charge) had produced sufficiently thick compacted layers on the internal surfaces of the mill to cushion impacts and prevent the attainment of the high pressures and shear necessary for conversion of calcite into aragonite.

Separate samples of the 1000-h milled Iceland spar were annealed for $2 \mathrm{~h}$ and $6 \mathrm{~h}$ at each of a series of fixed temperatures between 150 and $600^{\circ} \mathrm{C}$. The samples were annealed in air at temperatures below $250^{\circ} \mathrm{C}$, in dry nitrogen between $250^{\circ} \mathrm{C}$ and $450^{\circ} \mathrm{C}$, and in carbon dioxide between $500^{\circ}$ and $600^{\circ} \mathrm{C}$ (to prevent dissociation of $\mathrm{CaCO}_{3}$ which becomes appreciable in air above $500^{\circ} \mathrm{C}$ ). Techniques used to examine the samples were:

(a) Surface area determination by the adsorption of isotopica11y-1abe11ed krypton at $-196^{\circ} \mathrm{C}(8)$. Normally, the adsorption of krypton was measured after outgassing a sample for several hours in vacuo at $150^{\circ} \mathrm{C}$ followed by immediate cooling to $-196^{\circ} \mathrm{C}$ (9). The cross-sectional area of the krypton atom was taken as $19.5 \mathrm{~A}^{2}$, and the monolayer capacity was determined from the B.E.T. plot (10). The specific surface was reproducible within a standard deviation of $3 \%$.

(b) X-ray diffraction by means of a Solus-Schall diffractometer with a copper target on the $X$-ray generator. The method of Adams and Rowe (11) was used to prepare specimens with a flat surface for $X$-ray analysis. The angular width of the $10 \overline{14}$ calcite line in the diffraction patterns was measured at half-peak intensity and corrected by the method of Jones (12) to give the intrinsic broadening from which the apparent internal lattice strain normal to the 1014 planes could be calculated.

(c) Scanning and transmission electron microscopy.

(d) Meigen test (13) for comparing water solubility of the 2-h annealed calcitic samples in terms of the more soluble polymorph of calcium carbonate, aragonite; the defective and strained calcitic material represents a metastable condition which thermodynamically gives an increased solubility, rising towards that of aragonite. 
(e) Thermogravimetric analysis in an atmosphere of dry nitrogen at a constant rate of temperature rise, $3.1^{\circ} \mathrm{C} / \mathrm{min}$.

(f) Light-etching with dilute nitric acid, for dissolution of controlled amounts of calcium carbonate and determination of any sharpening of $\mathrm{X}$-ray lines as in (b). Samples were dried at $150^{\circ} \mathrm{C}$ and weighed before treatment with sufficient nitric acid to dissolve away 1, 10, or 100 molecular layers of $\mathrm{CaCO}_{3}$ from each particle. The amount of acid required was estimated approximately from the equivalent spherical diameter of the particles as calculated from the specific surface $(0.32 \mu \mathrm{m}$ for the $1000-\mathrm{h}$ milled sample), assuming the particles to be of uniform density 2.71 $\mathrm{g} / \mathrm{cm}^{3}$ for calcitic $\mathrm{CaCO}_{3}$.

\section{RESULTS AND DISCUSSION}

\section{A. Recovery of Crysta1linity by Thermal Treatment}

In Fig. 1, variations in specific surface, $\underline{S}$, are shown for samples of the 1000-h ground Iceland spar and precipitated calcitic calcium carbonate annealed for $6 \mathrm{~h}$ at a series of temperatures. There is a,decrease in $S$ for the ground Iceland spar of about $1 \mathrm{~m}^{2} \mathrm{~g}^{-1}$ on raising the annealing temperature from 150 to $175^{\circ} \mathrm{C}$. There is evidently some preliminary surface reordering at these surprisingly low temperatures. Then $S$ remains constant for stepwise increases in the annealing temperature to $300^{\circ} \mathrm{C}$, before progressively decreasing at higher temperatures to give a much less active solid $\left(S=c a .1 \mathrm{~m}^{2} \mathrm{~g}^{-1}\right)$ after annealing for $6 \mathrm{~h}$ at $600^{\circ} \mathrm{C}$. The sharp fall in $\mathrm{S}$ at temperatures above $300^{\circ} \mathrm{C}$ is ascribed, in the first instance, to sintering; the difference in free energy between the active and sintered solids provides the driving potential for the process. By comparison, the active precipitated calcite (of similar initial specific surface) begins to sinter at a temperature of $450^{\circ} \mathrm{C}$ (14). Thus, the effect of grinding the Iceland spar for $1000 \mathrm{~h}$ is to reduce the temperature for the onset of rapid sintering by about $100^{\circ} \mathrm{C}$ (from $450^{\circ}$ to $350^{\circ} \mathrm{C}$ ). The degraded crystal structure, indicated by $\mathrm{X}$-ray line broadening, and line intensity reduction, was very probably the cause of this temperature reduction; the production of point defects and dislocations would raise the free energy of the milled calcite above that of the precipitated calcite. The 


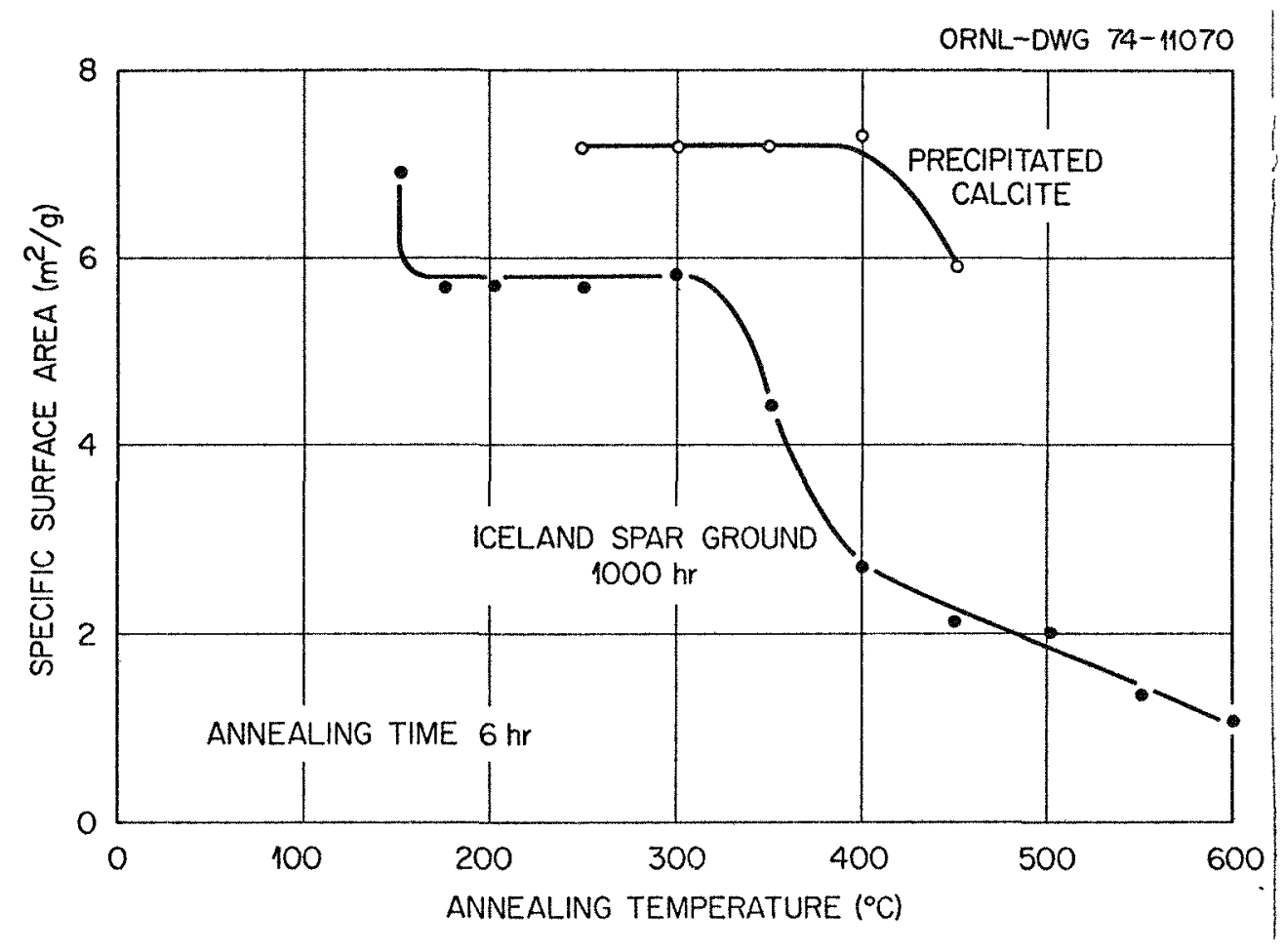

Fig. 2. Specific surface as a function of annealing temperature, using nitrogen or krypton adsorbate for the precipitated and ground calcite, respectively. The mean value of S for Iceland spar ground $2000 \mathrm{~h}$, after annealing and outgassing at $250^{\circ} \mathrm{C}$, is $6.92 \pm 0.7 .9 \mathrm{~m}^{2} / \mathrm{g}$ for ten separate determinations.

range of temperature $\left(300^{\circ}-350^{\circ} \mathrm{C}\right)$ over which sintering was first detected for the milled sample corresponds to $0.37-0.40$ of the melting point of the calcite, $1560^{\circ} \mathrm{K}$ (15), i.e., not much above one-third of the m.p. (in ${ }^{\circ} \mathrm{K}$ ) when sintering is expected to become possible by surface diffusion of ions $(16,17)$ for a highly active surface condition.

The recovery of crystallinity in ground calcite by thermal treatment is analogous to that of lunar dust grains. Those grains damaged by solar flare and wind particles start to sinter at about $600^{\circ} \mathrm{C}$. In comparison, fresh, undamaged dust grains sinter appreciably only at temperatures above $1100^{\circ} \mathrm{C} \mathrm{(18).}$

In support of the notion that surface reordering commences between $150^{\circ}-175^{\circ} \mathrm{C}$, the "surface solubility" also falls sharply (Fig. 2) in this temperature region. After annealing at $400^{\circ} \mathrm{C}$, 


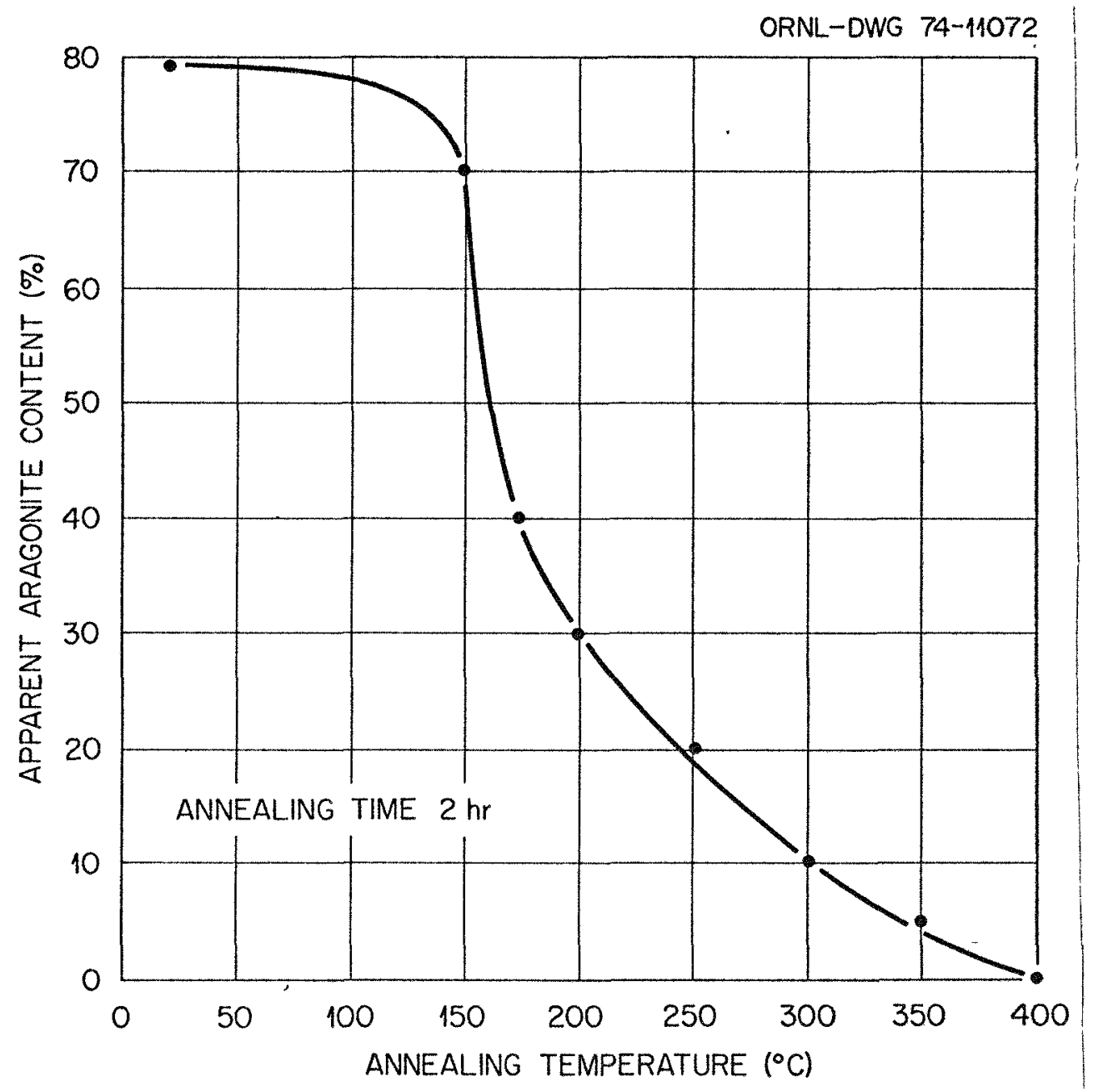

Fig. 2. The solubility of surface material in 2000-h milzed Iceland spar, measured by the Meigen color test, as a function of annealing temperature.

the milled Iceland spar shows the normal Meigen test reaction for calcite, indicating a normalization of the surface condition. The lattice strain, a bulk rather than a surface condition, requires higher temperatures for reduction and elimination as shown in Fig. 3. At $400^{\circ} \mathrm{C}$, for example, about one quarter of the apparent lattice strain still remains. At higher temperatures, $400-600^{\circ} \mathrm{C}$, the specific surface and apparent lattice strain decrease less rapidly, with the material being rendered nearly strain-free at $600^{\circ} \mathrm{C}$.

The overall recovery process is accompanied by increased crystalline outline in the microstructure, as illustrated in the electron micrographs of Figs. 4 and 5 . At these magnifications, however, changes in the external appearance of the grains are not detectable until the annealing temperature exceeds $350^{\circ} \mathrm{C}$. Micrographs of the 1000-h Iceland spar prior to annealing appear elsewhere (5). 


\section{|}

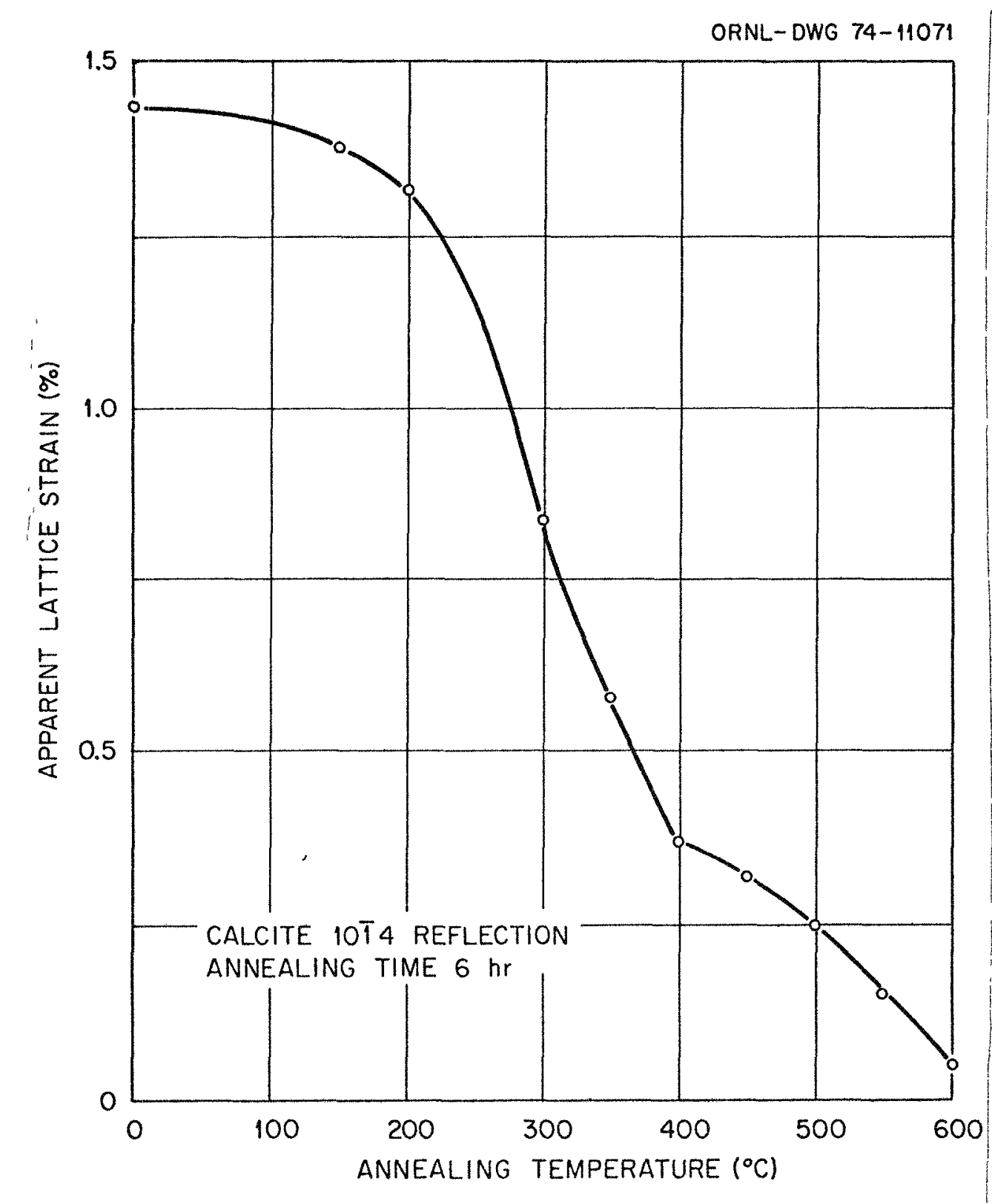

Fig. 3. Apparent Zattice strain of 2000-h milled Iceland spar from X-ray line broadening measurements as a function of annealing temperature.

Earlier researches on vacuum thermogravimetric analysis of calcareous materials (19) have shown the need to use temperatures of at least $200^{\circ} \mathrm{C}$ in vacuo and $250^{\circ} \mathrm{C}$ in air for the isotherma 1 outgassing of precipitated calcite samples. The difficulties of outgassing the precipitated and ground calcites used in this study are revealed in the thermogravimetric curves of Fig. 6. 


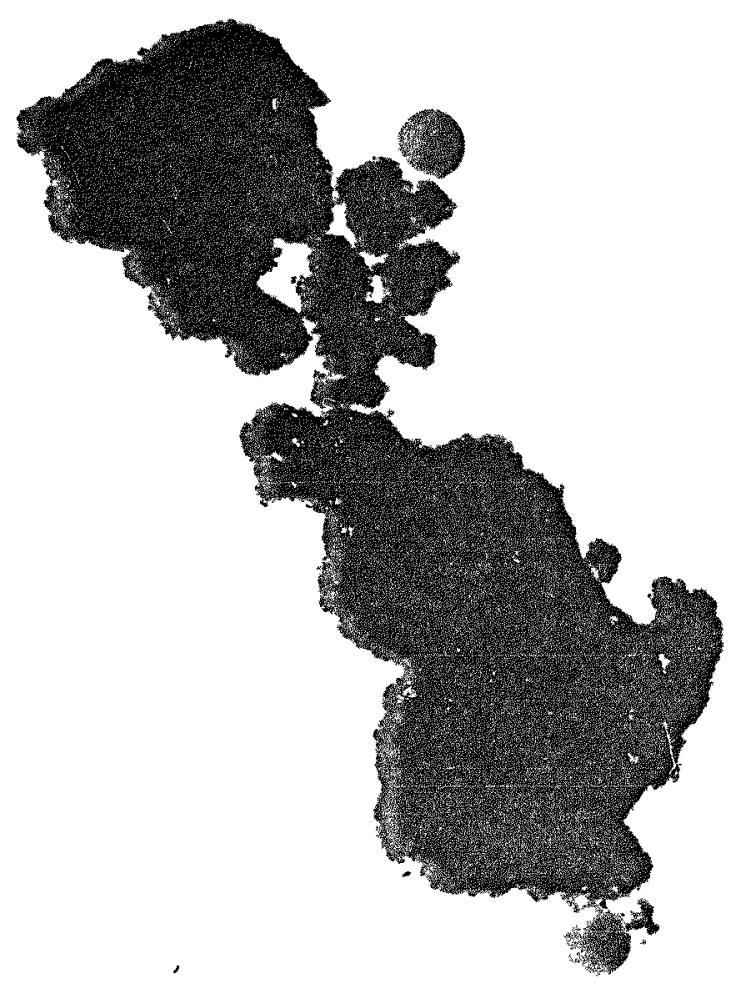

Fig. 4. Electron micrograph of Z000-h mizled Icezand spar annealed at $250^{\circ} \mathrm{C}$ for $20 \mathrm{~h}$; latex beads $0.26 \mathrm{\mu m}$ in diameter.

The manner in which water escapes from these samples is also informative of the recovery processes which are occurring.

The ground and precipitated calcites contained 2 and $>3 \%$ by weight of water, respectively. Most of the water in the ground Iceland spar had been adsorbed and then buried along fault lines within the grains during the plastic flow which took place throughout all but the first few hours of the milling $(2,5)$. The water in the precipitated calcite had been occluded during crystal growth in aqueous solution. As might be anticipated, escape of these buried waters was easier from the ground Iceland spar because of numcrous fault lines linking the bulk to the surface. Because of the reluctance of the precipitated calcite to yield 


\section{I}

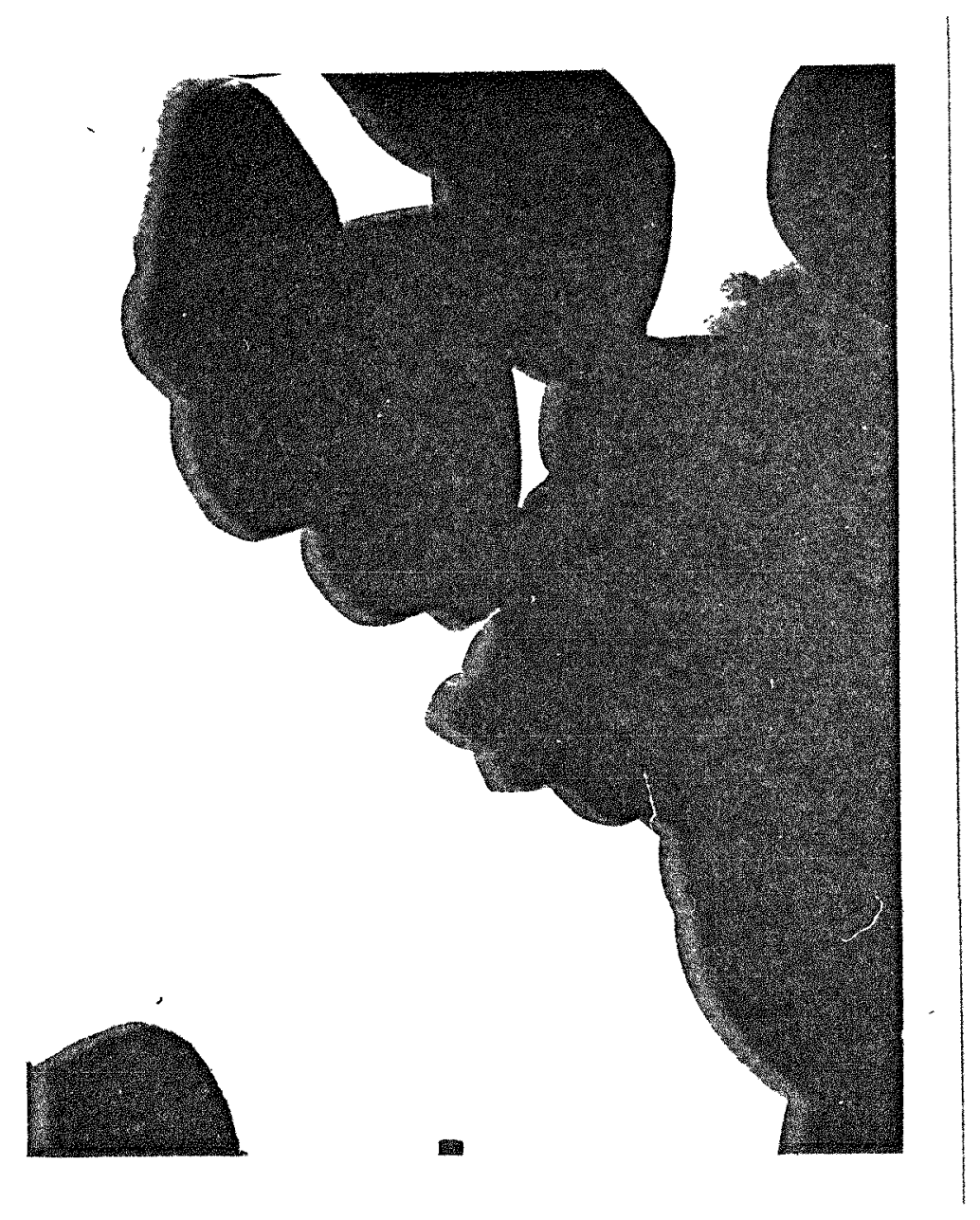

Fig. 5. Electron micrograph of 2000-h milled Iceland spar annealed at $600^{\circ} \mathrm{C}$ for $6 \mathrm{~h}$, same magnification as in Fig. 4. Grain growth has been extensive.

all of its occluded water, water was still being lost at about $550^{\circ} \mathrm{C}$, the temperature at which carbonate decomposition caused a measurable weight loss under these experimental conditions. In contrast, the weight of the ground Iceland spar was invariant from $450^{\circ}$ to $550^{\circ} \mathrm{C}$.

Each curve of Fig. 6 contains three peaks. The low temperature peak is associated with loosely held water not buried in the interior of the grains. Between $120-200^{\circ} \mathrm{C}$, water escapes quite rapidly, especially from the ground Iceland spar. At these temperatures, healing occurs rapidly in the surface region (Fig. 2). The third peak at 250$300^{\circ} \mathrm{C}$ coincides with the rapid elimination of strained material (Fig. 3 ) Venting of the water seems to be linked closely with the different healing processes taking place in different temperature ranges. 


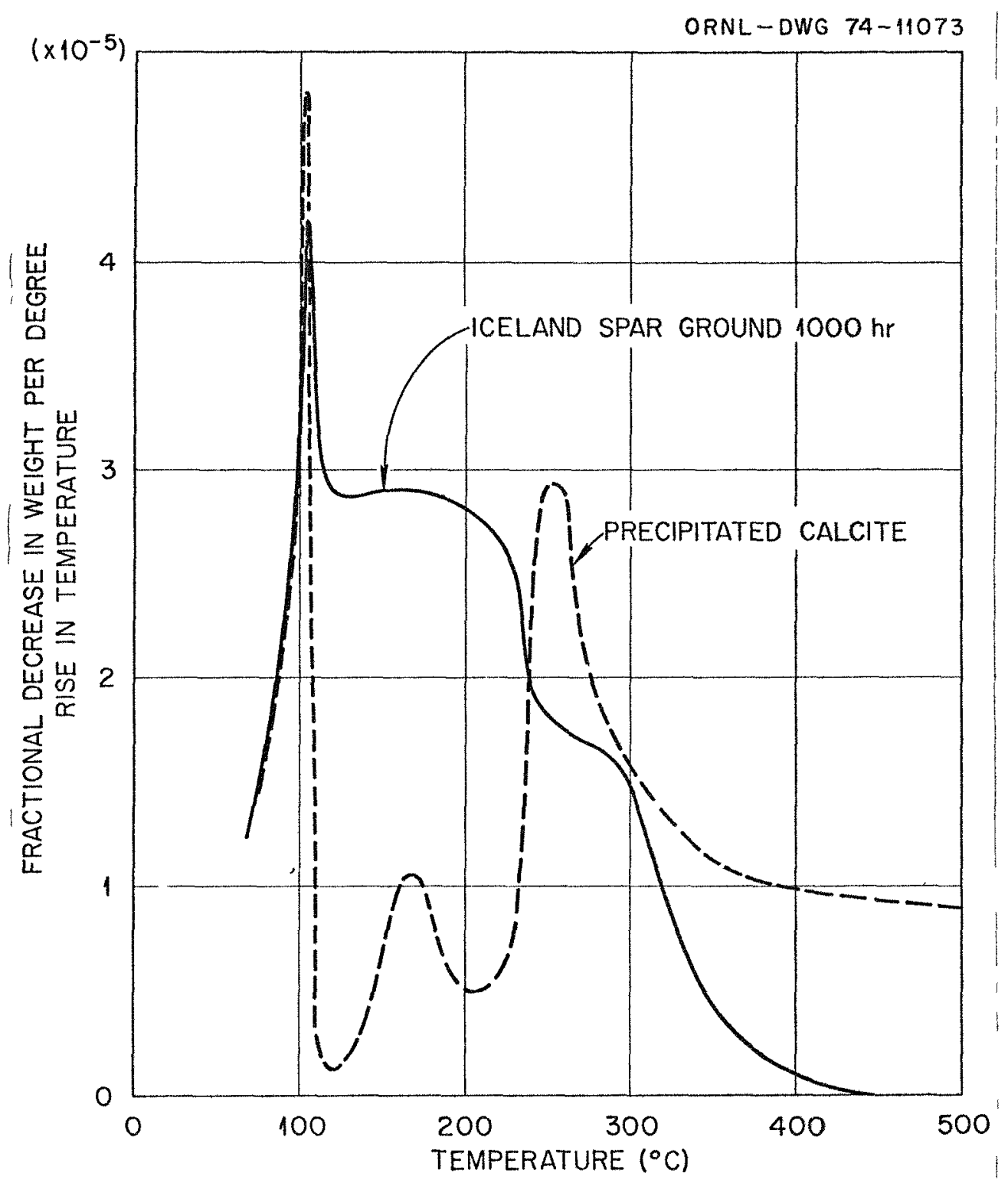

Fig. 6. Thermogravimetric analysis in a stream of dry nitrogen at a constant rate of temperature rise of $3.2 \% \mathrm{~min}$.

Access to the surface is more restricted in the precipitated calcite because of its greater degree of perfection. At $250^{\circ} \mathrm{C}$, this leads to nearly explosive expulsion of the remaining occluded water.

The healing processes occur in the following stages and with considerable overlapping. Reordering in the surface occurs first and is very marked between $150^{\circ}-200^{\circ} \mathrm{C}$. Relaxation of bulk lattice strains occurs primarily between $200^{\circ}$ and $400^{\circ} \mathrm{C}$. 
Sintering and loss of specific surface via the diffusion of surface ions is first noted at $350^{\circ} \mathrm{C}$. Healing of the surface is completed at $400^{\circ} \mathrm{C}$ whereas $600^{\circ} \mathrm{C}$ is required to give a nearly strain-free product. These final stages in the recovery of crystallinity are promoted by crystal lattice diffusion of ions and dislocations which become prominent above the Tammann temperature (20), which for calcite is about $780^{\circ} \mathrm{K}$ (half of the melting point in ${ }^{\circ} \mathrm{K}$ ). These growth movements permit the grains to assume the distinctly crystalline appearance shown in Fig. 5.

By analogy with the general behavior of cold-worked fabrics, the ground Iceland spar undergoes polygonization below the Tammann temperature, $i . e .$, the single strained grains tend to subdivide into several less strained subgrains having different orientations. This involves the migration of dislocations to form planar arrays at subgrain boundaries. Above the Tammann temperature, new nuclei develop in annealing recrystallization to produce unstrained crystals. The release of all stored strain energy completes the recovery from the initial strain hardened condition. With yet further prolonged heating, certain grains grow at the expense of other grains, and there is a general coarsening of the fabric of the material. Thus, in a strain-hardened solid of high specific surface, such as the ground Iceland spar, loss of specific surface by sintering and recovery from lattice defects can be expected to occur side by side. In several respects, they arise from the same causes, primarily the combined effects of ionic diffusion and movement of dislocations.

\section{B. Recovery of Crystallinity by Light-Etching}

The recovery of crystallinity is promoted also by lightetching for a few seconds with an aqueous mineral acid, such as nitric acid. Rapid removal of calcium carbonate, in amounts equivalent to 1 or 10 outer monolayers from each grain, reduced the apparent lattice strain by 17 and $22 \%$, respectively, as measured from the X-ray line broadening. Electron micrographs of the 1000-h ground Iceland spar treated with dilute nitric acid, Figs. 7,8 , and 9 , reveal that the light etching was accompanied by nearly spontaneous and extensive recrystallization. The products of recrystallization were whiskers (with the morphology of nail-head spar crystals of calcite) of the order $0.1 \mu \mathrm{m}$ in thickness, together with rhombs of calcite.

There are two prerequisites for this rapid and extensive recrystallization. First, the calcite must be in a structurallydegraded and lattice-distorted condition. Only in the Iceland spar ground in excess of 500 hours was this condition met $(2,5)$. 


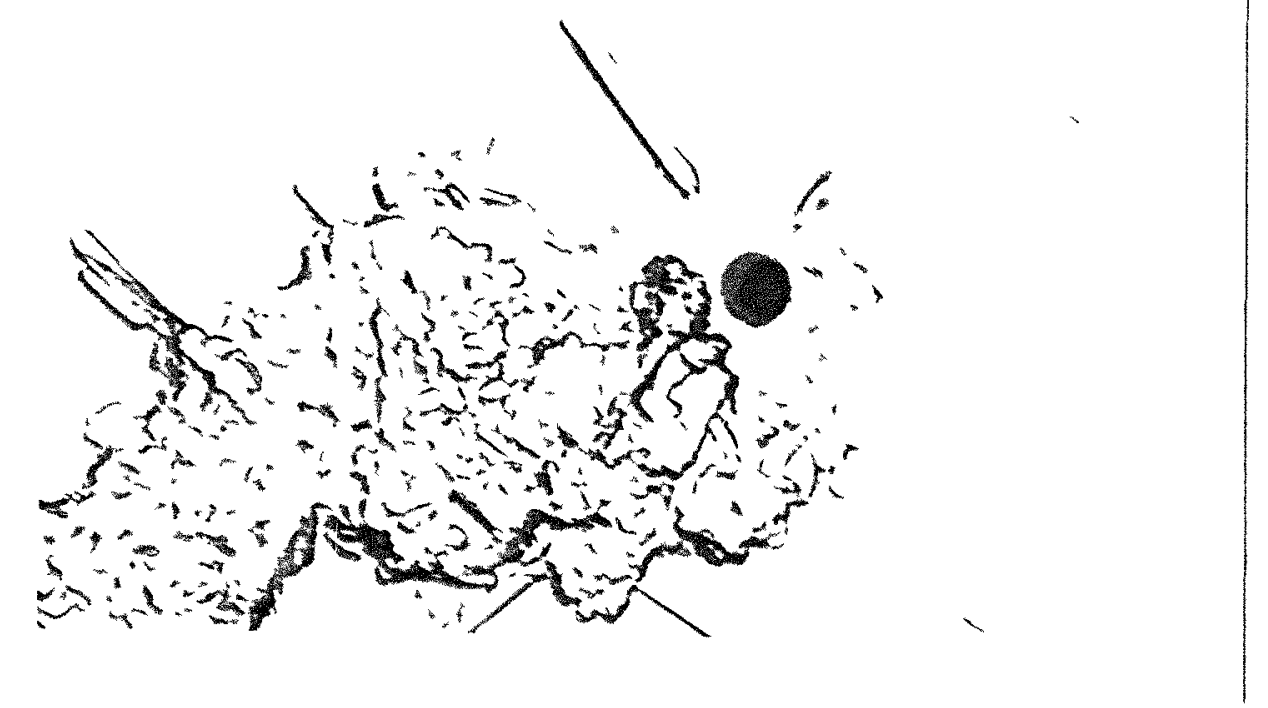

Fig. 7. Grain of 2000-hr mizled Iceland spar, after treatment with dilute nitric acid, showing predominantly whiskers of naithead spar calcite. The latex beads are 0.264 um in diameter.

This type of recrystallization could not be induced in Iceland spar samples ground for lesser times or in any samples of precipitated calcium carbonate. Furthermore, after the 1000-h Iceland spar had been in storage for 12 years, it had lost the capacity for etching-induced recrystallization. Presumably, relaxation of the severely-strained condition had taken place during this time period. These findings are in accord with those of Keith and Gilman (21) who etched moderately deformed calcite crystals with various acids; only dislocation etch pits were produced. There was no whisker growth or any other type of recrystalization.

The second prerequisite is a rapid attack of the surface. It appears that there must be an extensive and rapid perturbation of the surface condition to permit formation of the sites necessary for whiskers to grow from. In water, rather than dilute nitric acid, when the dissolution is much less drastic, whisker growth is rather slow. Exposure to water vapor at saturation pressure and at a temperature of $50^{\circ} \mathrm{C}$ for 50 days was necessary to produce the same amount of whisker growth as that promoted by a few seconds in dilute nitric acid. 


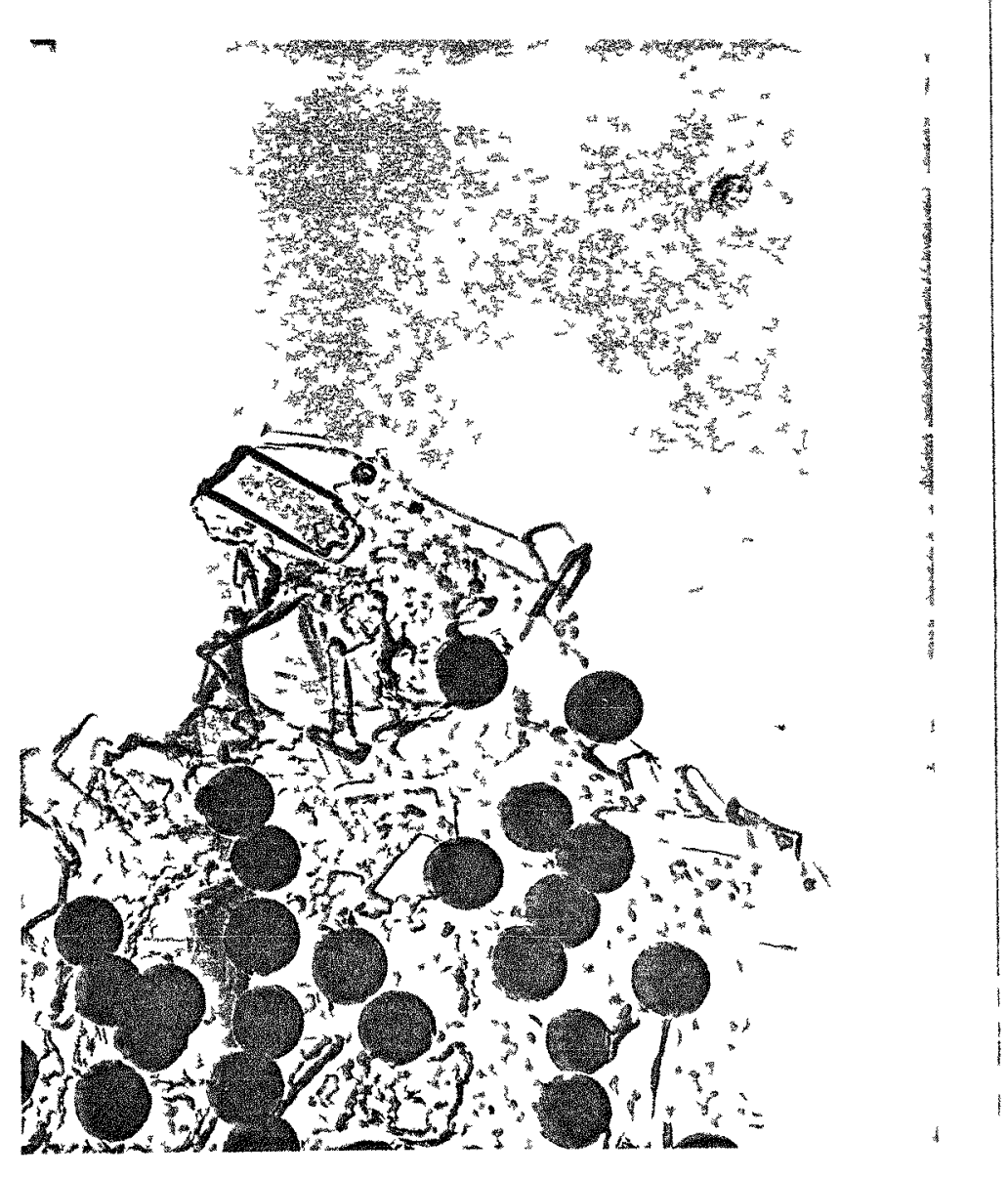

Fig. 8. Grain of 2000-h mizled Iceland spar, after dilute nitric acid treatment showing the mixed recrystallization products of nail-head spar and calcite rhombs. Latex beads $0.26 \mathrm{um}$ in diameter.

Amounts of acid sufficient to remove 1, 10, or 100 layers of $\mathrm{CaCO}_{3}$ produce nearly the same amount of recrystallized material. It seems to be the rapid attack of the surface which txiggers formation of the maximum number of growth sites rather than the total amount of $\mathrm{CaCO}_{3}$ removed.

One can speculate that the whisker growth is taking place by a modified dislocation growth mechanism $(22,23)$. Lattice strain is caused by pile-ups of dislocations against barriers, and evidently the surface acts as a particularly effective barrier due, perhaps, to the effects of space charge repulsion. Rapid dissolution of $\mathrm{CaCO}_{3}$ in the surface would release the dislocation pile-ups enabling steps to form on the surface about which the whiskers can grow. 


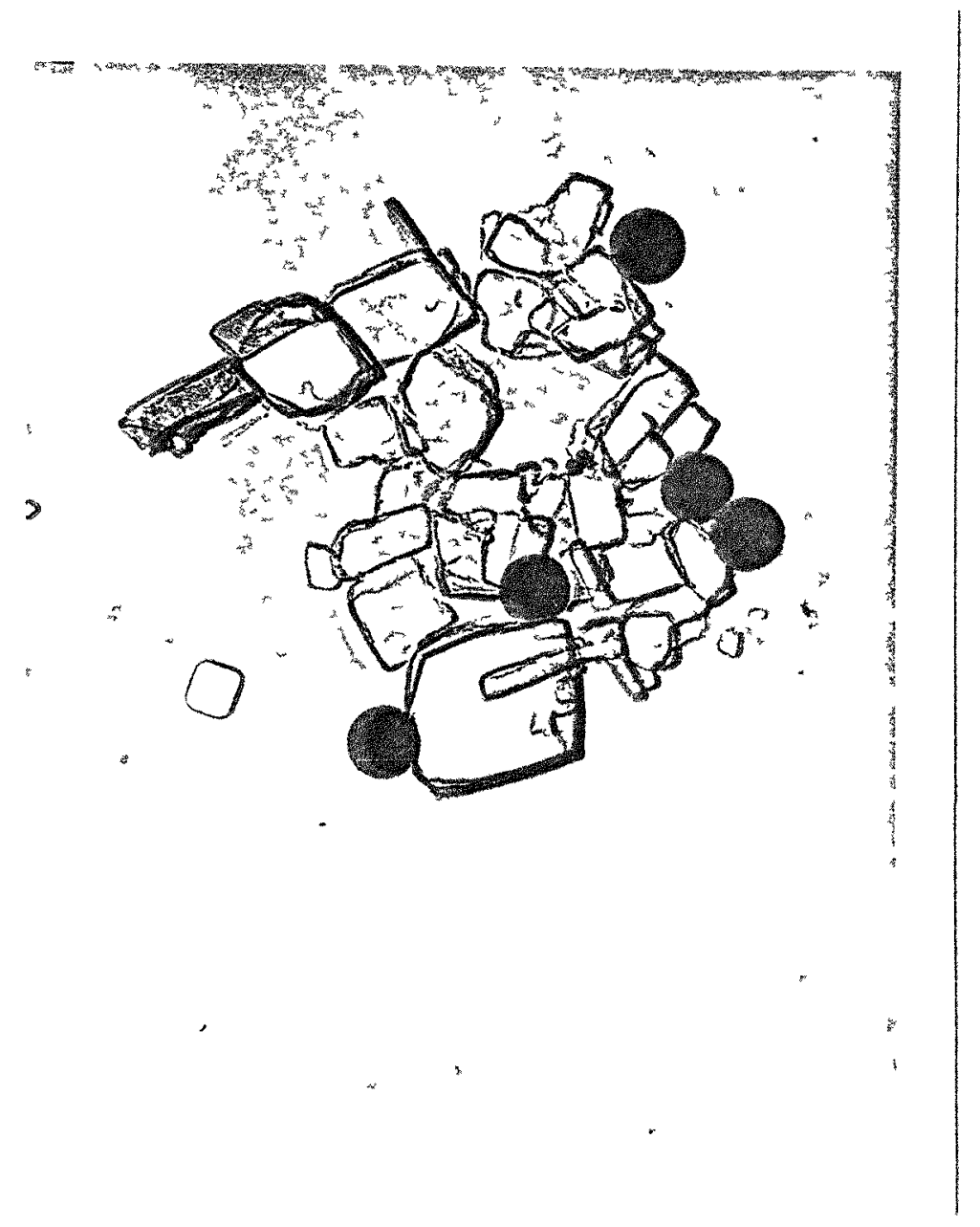

Fig. 9. Cluster of recrystallization products, mainly calcite rhombs, in 2000-h milled Iceland spar treated with nitric acid. Latex beads $0.26 \mathrm{um}$ in diameter.

IV. SUMMARY

Iceland spar structurally degraded by 1000 hours of grinding exhibits recovery processes starting at temperatures as low as $150^{\circ}-175^{\circ} \mathrm{C}$. Surface reordering starts first and is detected as a rapidly falling solubility (Meigen test) and a $15 \%$ decrease in apparent specific surface determined by krypton sorption. Surface reordering is completed at $400^{\circ} \mathrm{C}$. Return of crystallinity to the bulk, by the measures of growth in particle size and reduction in lattice strain, requires higher temperatures. A temperature of $600^{\circ} \mathrm{C}$ is necessary to produce a strain-free product. 
Perturbation of the surface by an etchant triggers sive recrystallization and whisker growth in 1000-h Iceland spar. Storage of the reactive material for 12 years results in loss of the ultrareactivity presumably through relaxation of internal strains.

\section{REFERENCES}

1. Gammage, R. B., and Glasson, D. R., Chem. Ind., London, 1466 (1963).

2. Gammage, R. B., Ph.D., Thesis, Exeter University, England (1964).

3. Lewis, D., and Northwood, D. 0., Amer. Min. 53, 2089 (1968).

4. Gammage, R. B., and Gregg, S. J., J. Colloid Interface Sci., 38,118 (1972).

5. Gammage, R. B., Holmes, H. F., Fuller, E. L., Jr., and Glasson, D. R., J. Colloid Interface Sci., 47, 350 (1974).

6. Gammage, R. B., and Glasson, D. R., J. Colloid Interface Sci., (1976) in press.

7. Lewis, D., and Northwood, D. 0., Canadian Min. 10, 216 (1970).

8. Aylemore, D. W., and Jepson, W. B., J. Sci. Instr., 38 156 (1961).

9. Gammage, R. B., and Holmes, H. F., in press, "Recent Advances in Colloid and Surface Science", Academic Press.

10. Brunauer, S., Emmett, P. H., and Teller, E., J. Amer. Chem. Soc., 60,309 (1938).

11. Adams, L. H., and Rowe, F. A., Amer. Min., 39, 215 (1954).

12. Jones, F. W., Proc. Roy. Soc., (a) 166, 16 (1938).

13. Meigen, H., Ber. Naturforsch. Ges., 15, 38 (1905).

14. Glasson, D. R., J. App1. Chem., London, 11, 28 (1961) .

15. Boeke, H. E., Neues Jahrb. Min., 91 (1), 1 (1912). 
16. Hüttig, G. F., Kolloidzschr., 98, 6203 (1942).

17. Gregg, S. J., J. Chem. Soc., 3940 (1953).

18. Maurette, M. and Price, P. B., Science, 187, 121 (1975).

19. Glasson, D. R., "Analysis of Calcareous Materials", Soc. Chem. Ind., Monogr., No. 18, 401 (1964) (London: The Society).

20. Tammann, G., Z. Anorg. Chem., 176, 46 (1928).

21. Keith, R. E., and Gilman, J. J., Acta Met., 8, 1 (1960).

22. Eshe1by, J. D., Phys. Rev., 91, 755 (1953).

23. van Bueren, H. G., "Imperfections in Crystals", North Holl and (1960). 